UDC: 316.772 .4

DOI: https://doi.org/10.24195/2414-4665-2017-7-10

Liliia Homolska, teacher of social sciences,

R. Glier Kyiv Institute of Music,

Doctoral candidate, Department of Social Psychology, Taras Shevchenko National University of Kyiv, Kyiv, Ukraine.

\title{
TYPES OF CONSUMERS ACCORDING TO THEIR PERCEPTIONS OF BRANDS' ENVIRONMENTAL FRIENDLINESS IN BRAND COMMUNICATIONS
}

The article presents the results of the research on the peculiarities of Ukrainian consumers' perception of brands' environmental friendliness in brand communications. Brand communications are a set of specific actions in social interaction process (interpersonal, intergroup, mass-scale) that affect the opinions, motives, attitudes and behaviour of consumers towards certain companies, their products and (or) services. The result of brand communications is the image of a brand as a social object. The effectiveness of brand communications results in the formation of consumers' loyalty as an attitude, which is developed dynamically and motivates individuals to buy and consume a certain product (service). There have been presented the results of empirical research that outline the types of consumers according to their perception of brands' environmental friendliness in brand communications. Besides, there have been identified statistically significant differences in categorization of consumer types, depending on a number of socio-demographic and professional factors; the impact of brand equity on loyalty as a socio-psychological mechanism of effective brand communication for food products. The prospects of further studies involve the determination of psychosocial mechanisms and factors of effective brand communications, theoretical justification, development and testing of social and psychological training programs for future managers, marketing specialists, advertising sector employees aimed at developing brand communications skills.

Keywords: brand, brand image, environmental friendliness of a brand, attitude, brand communication, consumer's psychology, loyalty.

\section{Introduction}

The ongoing social and economic transformations result in currently changing attitudes in the minds of individuals towards a greater social responsibility in human relations with the environment. One of the things proving it is a growing consumers' demand for environmentally friendly products and, accordingly, the emergence of ecomarketing, aimed at the development of the methods of promotion and selling of such products or services $(\mathrm{N}$. Golechyan [5]).

Environmental friendliness gradually becomes a part of the mandatory perceptions of a brand, affects the formation of a positive attitude towards it. Thus, in case a product is given the reputation of environmentally friendly, it is about stimulation of not only economic, but also moral intentions of consumers. Because eco-friendliness assumes changes in perception of a brand in the context of impact on the environment in general and each individual in particular. Appealing to environmental awareness of an individual, brand communicator encourages him/her to think not only about of his/her own and his/her family's safety, but also about the future, other people and the state of our planet in general (Yu. Brovkina [4], G. Felser [10]).

In this regard, special attention is paid to studying the peculiarities of brand perception by individuals in the process of brand communications, taking into account their influence on the environment and the livelihood of a particular individual.
It should be noted that various aspects of brand communications have already been the subject of researchers' attention, in particular, they studied various psychological aspects of the formation and functioning of a brand (G. Andreieva [2], J. Gabay [16] and others), among other things from the management positions (D. Aaker [1] and other); brand communications as a psychosocial phenomenon (Yu. Brovkina [4], F. Sharkov [13] etc.).

On the other hand, some researchers have been dealing with ecological approach in the psychology of perception (V. Barabanschikova [3] and others); environmental principle as the basic one in the environmental psychology (A. Liovochkina [6], Yu. Shvalb [14] and other), ecological awareness and modern lifestyle (O. Vernik [14], O. Harnets [14], A. Liovochkina [6], V. Skrebets [9], Yu. Shvalb [14] etc.), including in environment-focused occupation (N. Golechyan [5], O. Palamarchuk [8]). These studies show the role of ecological compatibility and environmental awareness principle as important determinants of the mass consciousness, correction of modern lifestyles, environmental development of production and development of human relations with the environment.

At the same time the role of environmental friendliness principle in the context of brand communications efficiency is not adequately covered. As part of the specified topic it is possible to single out only research of social perception of ecological compatibility argument in 
brand communications (Yu. Brovkina [4]) on small sampling of Russian consumers.

Therefore, the relevance and insufficient study of ecological friendliness phenomenon of brands as a factor of brand communications efficiency determined the goal of this research.

The paper aims to investigate and distinguish consumer types according to the features of perceiving the environmental friendliness of brands in brand communications

\section{Research Methods}

Brand communications are a set of specific actions in social interaction process (interpersonal, intergroup, mass-scale) that affect opinions, motives, attitudes and behaviour of consumers towards certain companies, their products and (or) services. The result of brand communications is the image of a brand as a social object [4; 15].

The effectiveness of brand communications results in consumers' loyalty as an attitude, which is developed dynamically and motivates individuals to purchase and consume a certain product (service)]; 17, etc.].

Environmental friendliness of a brand can be such a motivating factor as the way to persuade consumers in environmental safety of the products, manufactured under this brand, for humans and environment, and, consequently, social responsibility of their manufacturer $[4 ; 6$, etc.].

We have conducted an empirical study to examine the influence of brands' environmental friendliness on the efficiency of brand communications.

1000 persons participated in the research, who were selected using a randomization technique from residents of all regions of Ukraine. They were subdivided into groups according to: 1$)$ sex $(48.2 \%$ of men and $51.8 \%$ of women); 2) age $(32.1 \%$ of respondents are under 30 ; $30.1 \%$ - from 30 to 40 years old; $37.8 \%$ - from 40 to 55 years old); 3 ) education (secondary education $-10.3 \%$, vocational education $-20.0 \%$, higher education $-74.2 \%$ ); 4) place of residence $(20.1 \%$ - centre; $79.9 \%$ - regions $)$; $5)$ occupation (10.6\% of senior and middle managers;
$8.1 \%$ of entrepreneurs and farmers; $40.7 \%$ of specialists from different spheres of economy; $7,5 \%$ of employees, including public sector; $3.8 \%$ of workers; $3.2 \%$ of retired people; $5.3 \%$ of students; $20.8 \%$ of housewives and persons without definite occupation); 6) level of income per family member $(46.2 \%$ of respondents - below UAH $2000 ; 40.1 \%$ - from UAH 2000 to $5000 ; 13.7 \%$ - over UAH 5000).

We chose a questionnaire by $\mathrm{Yu}$. Brovkina as the main research methodology [4], modified by us with account for specific features of manufacturers present at the Ukrainian market. The questionnaire consists of two blocks of questions. The first set of questions is associated with the understanding of the role of brand's environmental friendliness in brand communications of different levels and its influence on the purchase of a certain product. The second set of questions is aimed at identification of common brands represented in the Ukrainian market, that are environmentally-friendly according to consumers.

The loyalty of the respondents to the brands of certain goods or services was studied using Net Promoter Score Method by Fred Reichheld (NPS [11; 18]). The respondents were offered to assess the probability that they recommend a brand to their friends and colleagues, using a scale from 0 to 10 . According to the study, respondents were assigned to one of three groups by degree of consumers' loyalty: 1) promoters (8-10 points) - high level of loyalty to a brand; 2) passive customers (3-7 points) - average level of loyalty; 3 ) detractors (0-2 points) - low level of loyalty.

Data processing was carried out using statistical and mathematical methods ( $\chi^{2}$ criterion, factor, cluster and dispersion analysis) using SPSS computer program (version 17.0).

\section{Research Results and their Discussion}

At the first stage of empirical research the respondents were categorized by their understanding of the role of brand's environmental friendliness (Table1).

Categorization of the respondents by their understanding

Table 1. of the role of brand's environmental friendliness

\begin{tabular}{|l|c|}
\hline In what situations do you think about eco-friendliness of a brand? & Percentage of respondents \\
\hline When I buy food & 45.2 \\
\hline Every time I buy goods & 33.3 \\
\hline When I see an eco-label & 24.6 \\
\hline When my friends talk about it & 17.4 \\
\hline When this topic is discussed in mass media & 17.1 \\
\hline When this topic is discussed on the Internet & 13.7 \\
\hline When I get to know manufacturer's reasoning & 13.2 \\
\hline When I see this brand advertised & 12.2 \\
\hline I don't think about it at all & 17.0 \\
\hline
\end{tabular}

As it comes out of the data presented in Table 1, most of all environmental friendliness of a brand is associated with food products ( $45.2 \%$ of respondents). At the same time, environmental friendliness of brands plays a significant role for any group of goods for $33.3 \%$ of the surveyed consumers; and the presence of eco-labels is important for $24.6 \%$ of the respondents. 
Environmental friendliness of a brand is actualized in case of discussion by consumers' friends (17.4\%), in mass media $(17.1 \%)$, in Internet (13.7\% of respondents), etc. One becomes interested in environmental friendliness of a brand when checking out manufacturers' reasoning $(13.2 \%)$ or an advertising of the product (12.2\%). Only for $17.0 \%$ of the respondents environmental friendliness of a brand is not a significant factor of brand communications.

Based on the results of factor analysis of the respondents' answers we have identified three factors that determine the significance of brands' environmental friendliness in brand communications and cover $61.5 \%$ of the total dispersion (Table 2).

Table 2.

Results of factor analysis of brand's eco-friendliness importance in brand communications

\begin{tabular}{|c|c|c|c|}
\hline \multirow{2}{*}{$\begin{array}{l}\text { I think about environmental compatibility of a } \\
\text { brand... }\end{array}$} & \multicolumn{3}{|c|}{ Factors } \\
\hline & 1 & 2 & 3 \\
\hline When buying food & & 0.674 & \\
\hline Every time I buy goods & & 0.704 & \\
\hline When I see eco-label & & & 0.483 \\
\hline When my acquaintances talk about it & 0.712 & & \\
\hline When this topic is discussed in mass media & 0.720 & & \\
\hline When this topic is discussed in Internet & 0.587 & & \\
\hline When I get to know manufacturer's reasoning & & & 0.805 \\
\hline When I see this brand advertised & 0.537 & & \\
\hline I don't think about it at all & & -0.766 & \\
\hline
\end{tabular}

The first factor (30.2\% of total dispersion) includes respondents' answers about the awareness of the role of brand's environmental friendliness in case it is discussed in mass media $(0.720)$; by friends $(0.712)$; in Internet (0.587); in advertising $(0,537)$. This gives grounds to speak about orientation of these consumers to conventional level of brand communications.

The second factor ( $20.5 \%$ of total dispersion) is bipolar and highlights the features of brand communications from the consumer's prospective, when the environmental friendliness gains personal meaning for him/her: I think about environmental friendliness of a brand every time I purchase goods $(0.704)$ or when purchasing food products (0.674) and the opposite pole is "I do not think of it at all" $(-0.766)$.

The third factor ( $10.8 \%$ of the total dispersion) characterizes environmental friendliness based on brand im- age created by a manufacturer: I think about environmental friendliness of a brand when I get to know the manufacturer's reasoning (0.805); when I see eco-labels (0.483).

The obtained results are consistent with sociopsychological model of brand communication developed by $\mathrm{Yu}$. Brovkina, which has the following components: 1) conventional meaning, determined by the influence of mass media; 2) personal meaning, dependent on personal characteristics of an individual, that are shown in the decision making process when choosing a particular brand; 3 ) brand image created by a manufacturer [4].

According to the results of cluster analysis based on factor analysis, there are 4 types of consumers by perception of brand's eco-friendliness in brand communications (Table 3).

Table 3.

Types of consumers by perception of brand's eco-friendliness in brand communications (based on the results of cluster analysis)

\begin{tabular}{|l|c|}
\hline \multicolumn{1}{|c|}{ Types } & Percentage of respondents \\
\hline Focused on personal significance of brand's eco-friendliness & 43.7 \\
\hline Not focused on eco-friendliness of a brand & 30.1 \\
\hline Focused on brand image created by a manufacturer & 11.8 \\
\hline Focused on conventional level of brand communications & 14.4 \\
\hline
\end{tabular}

The first cluster involves $43.7 \%$ of the respondents, they are focused on personal significance of brand's environmental friendliness. The second cluster $(30.1 \%)$ consists of the respondents, who are basically not focused on environmental friendliness of a brand. The respondents belonging to the third cluster $(11.8 \%)$ are mostly focused on a brand image created by a manufacturer. The fourth cluster $(14.4 \%)$ consists of the respondents, for whom the environmental friendliness of a brand becomes relevant in case of conventional level of brand communications.

At the same time, we have detected statistically significant difference in distribution of consumer types, depending on a number of socio-demographic and professional factors. For instance, according to $\chi^{2}$ criterion we have found statistically significant differences in categorization of consumer types based on sex: women are fo- 
cused on personal significance of brand's eco-friendliness more than men ( $48.8 \%$ of women; $38.2 \%$ of men), while men show their non-focus on brand's environmental friendliness slightly more than women $(33.8 \%$ of men; $26.6 \%$ of women $(\mathrm{p}<0,01)$.
Moreover, we have discovered age characteristics of consumers' perception of brand's environmental friendliness in brand communications (Table 4).

Age features of the types of consumers according to the perception

Table 4. of the brand's environmental friendliness in brand communications

\begin{tabular}{|l|c|c|c|c|}
\hline \multirow{2}{*}{ Age groups } & \multicolumn{4}{|c|}{ Types of consumers by perception of brand's environmental friendliness in brand communica- } \\
& $\begin{array}{c}\text { tions, percentage of respondents } \\
\text { Focused on the per- } \\
\text { sonal significance of } \\
\text { brand's environmen- } \\
\text { tal friendliness }\end{array}$ & $\begin{array}{c}\text { Not focused on eco- } \\
\text { friendliness of a } \\
\text { brand }\end{array}$ & $\begin{array}{c}\text { Focused on the brand } \\
\text { image created by a } \\
\text { manufacturer }\end{array}$ & $\begin{array}{c}\text { Focused on conven- } \\
\text { tional level of brand } \\
\text { communications }\end{array}$ \\
\hline Under 30 & 35.8 & 33.3 & 11.8 & 19.1 \\
\hline From 30 to 40 & 42.2 & 31.2 & 11.3 & 15.3 \\
\hline From 40 to 55 & 51.6 & 26.4 & 12.2 & 9.8 \\
\hline
\end{tabular}

As it comes out of Table 4, with aging the consumers' focus on personal significance of brand's environmental friendliness increases; at the same time, the younger respondents mostly are focused on the conventional level of brand communications or not focused on environmental friendliness of a brand as a regulator for customer behaviour $(\mathrm{p}<0,01)$.

Similar tendency was noticed with regard to the level of the respondents' education: if among the respondents with primary or incomplete secondary education there are $20 \%$ of those focused on personal significance of brand's environmental friendliness, the same opinion among the respondents with higher education is shared by $46 \%$. But also among the respondents with primary or incomplete secondary education there are more of those, who are focused on brand image created by a manufacturer $(40 \%)$, while there are only $12.7 \%$ of them among the respondents with higher education $(\mathrm{p}<0,05)$.
It is noteworthy that by occupation, place of residence and level of income we have detected no significant differences in categorization of consumer types by perception of brand's environmental friendliness in brand communications. This is only about the slight tendency ( $p$ $=0,187$ ) regarding the respondents' occupation: among senior and middle managers and retired people there are more of those focused on personal significance of brand's eco-friendliness $(48.1 \%$ and $56.3 \%$ respectively) compared to other categories of the respondents. However, a significant number of the surveyed workers $(36.8 \%)$ are scarcely focused on environmental friendliness of a brand compared to other groups of the respondents.

At the next stage of our empirical research, we categorized the respondents by assessment of eco-friendliness among brands of different groups of goods and services (Table 5).

Table 5.

Categorization of the respondents according to assessment of environmental friendliness of a brand

\begin{tabular}{|l|c|}
\hline \multicolumn{1}{|c|}{ Brand } & Percentage of the respondents \\
\hline Nasha Ryaba (chicken meat) & 36.8 \\
\hline Roshen (sweets) & 25.4 \\
\hline Chernihivske (beer) & 21.4 \\
\hline Molokiya (dairy products) & 18.9 \\
\hline Samsung & 18.5 \\
\hline PrivatBank (bank) & 14.9 \\
\hline MTS (GSM provider) & 14.3 \\
\hline Toshiba & 9.0 \\
\hline Louis Vuitton & 8.0 \\
\hline Coca-Cola & 4.1 \\
\hline Lush & 2.7 \\
\hline Lukoil (oil company) & 1.7 \\
\hline None of the brands are selected as eco-friendly & 6.9 \\
\hline
\end{tabular}

As it comes out of table 5, environmental friendliness of a brand in consumers' perception is associated with food products, especially ("Nasha Ryaba" (36.8\%),
"Roshen" (25.4\%), "Chernihivske" (21.4\%), "Molokiya" $(18.9 \%)$ ), which is consistent with the results from previ- 
ous studies on the environmental friendliness of food product brands [4].

At the same time, attention is drawn to changes in perceptions of consumers, who find environmental friendliness of a brand significant for some non-food items: Samsung (18.5\%) or services: PrivatBank (14.9\%), MTS (14.3\% of respondents).
At the final stage of empirical research, based on the results of dispersive analysis, we discovered peculiarities of the respondents' loyalty to a certain brand depending on the assessment of its environmental friendliness.

In particular, we have detected statistically significant differences in loyalty towards food group of goods depending on the environmental assessment of their brand (Fig.1).

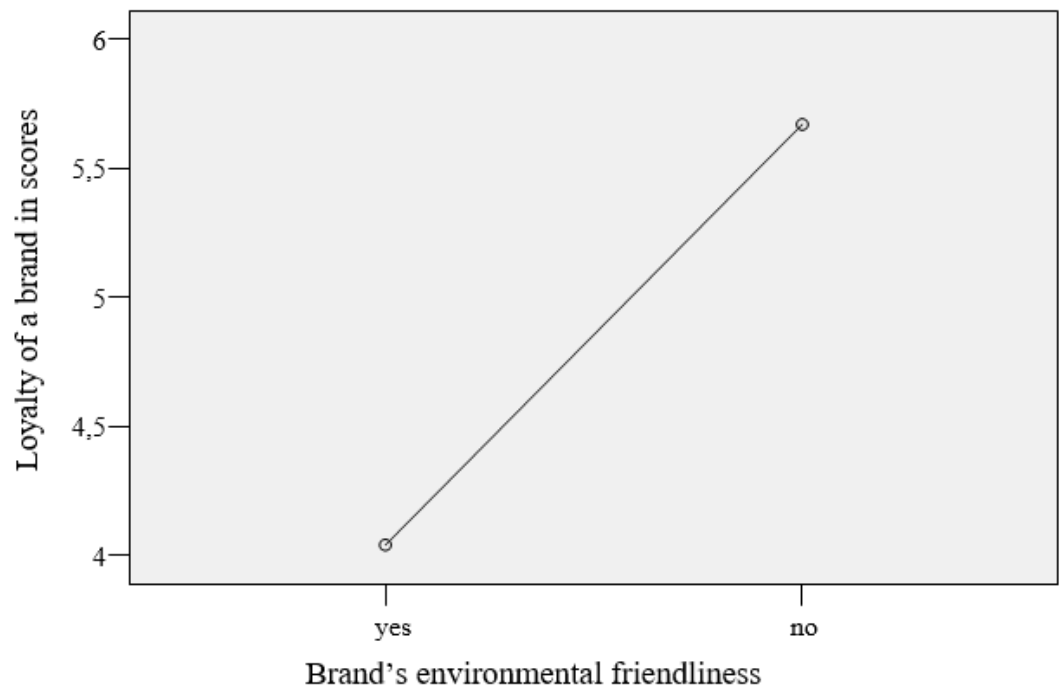

Fig. 1. Peculiarities of customers' loyalty to "Roshen" brand depending on their assessment of its environmental friendliness (based on results of dispersion analysis).

As can be seen from Fig. 1, in case "Roshen" is recognized as an environmentally friendly brand, the consumers' loyalty to it increases $(\mathrm{p}<0,01)$.

Similar results have been obtained about other groups of goods as well. Therefore, the peculiarities in perception of brand's environmental friendliness in brand communications among Ukrainian consumers have been confirmed.

\section{Conclusion}

Based on the results of the scientific literature review, it has been determined that brand communications are a set of specific actions in social interaction process (interpersonal, intergroup, mass-scale) that affect opinions, motives, attitudes and behaviour of consumers towards certain companies, their products and (or) services. The result of brand communications is the image of a brand as a social object.

Based on the empirical research outcomes it has been confirmed that environmental friendliness of a brand is an important factor of brand communications' efficiency.

The results of cluster analysis based on factor analysis has made it possible to single out 4 types of consumer perception of brand's eco-friendliness in brand communications: focused on personal significance of brand's ecofriendliness, focused on brand image created by manufacturers, focused on conventional level of brand communi-

\section{REFERENCES}

1. Aaker, D. (2003). Sozdanie silnykh brendov [Building powerful brands]. Moscow: Grebennikov Publishing House [in Russian]. cations, not focused on environmental friendliness of a brand.

We have determined statistically significant differences in categorization of customer types depending on social-demographic and institutional-occupational factors. For instance, women are focused on personal significance of brand's environmental friendliness more than men, but most of men are not focused on eco-friendliness of a brand at all. Among the group of younger consumers there are more of those focused on conventional level of brand communication or not focused on environmental friendliness of a brand as a regulator of consumer behaviour $(\mathrm{p}<0,01)$.

Based on the results of dispersive analysis we have determined peculiarities in Ukrainian consumers' perception of brand's eco-friendliness in brand communications and customer loyalty as a factor of effective brand communication for food group of goods.

The prospects of further studies will be aimed at the determination of psychosocial mechanisms and factors of effective brand communications, theoretical justification, development and testing of social and psychological training programs for future managers, marketing specialists, advertising sector employees to effective brand communications. 
3. Barabanschikova, V. A. (1989). Osnovnye napravleniya i tendentsii razvitiya psikhologii vospriyatiya [The main directions and tendencies of perceptual psychology development]. Psikhologiya vospriyatiya: Materialy sovetsko-norvezhskogo simpoziuma - Perceptual psychology: Materials of Soviet-Norwegian Symposium (pp. 5-14). Moscow: Nauka [in Russian].

4. Brovkina, Yu. Yu. (2009). Sotsialnopsikhologicheskie osnovy brend-kommunikatsiy: monohrafiia [Social and psychological basic concepts of brand communication: monograph]. Moscow: Published by Moscow Humanitarian University [in Russian].

5. Golechyan, N. (2008). Eko-marketing: v chem vygoda ekologicheski blagopoluchnogo imidzha kompanii [Eco marketing: what is the benefit of environmentally safe image of the company]. Korporativnaya imidzhelogiya Corporate image studies, 2 (3), 50-55 [in Russian].

6. Liovochkina, A. M. (2010). Pryntsypy pozytyvnosti i konstruktyvnosti ta ekolohichnosti yak bazovi pryntsypy ekolohichnoi psykholohii [Principles of positivity, constructability and environmental friendliness as basic principles of environmental psychology]. Aktualni problemy psykholohii: zb. nauk.pr. Instytutu psykholohii imeni H. S. Kostiuka APN Ukrainy - Current issues in psychology: collection of scientific papers of the Institute of psychology named after G. S. Kostiuk, National Academy of Educational Science of Ukraine, 24, 160-166. S. D. Maksymenko (Ed.). Kyiv [in Ukrainian].

7. Mozer, K. (2004). Psikhologiya marketinga i reklamy [Psychology of marketing and advertising]. Kharkiv: Humanitarian Centre publishing house [in Russian].

8. Palamarchuk, O. M. (2014). Ekolohichno oriientovana pidpryiemnytska diialnist $u$ suchasnomu sviti: psykholohichni aspekty: monohrafiia [Environmentally oriented business activity in the modern world: psychological aspects: monograph]. Zhytomyr: Published by Zhytomyr State University named after I. Franko [in Ukrainian].

9. Skrebets, V. O. (2004). Ekolohichna psykholohiia u viddalenykh naslidkakh ekotekhnohennoi katastrofy: monohrafiia [Environmental psychology in the long-term

\section{ЛІТЕРАТУРА}

1. Аакер Д. Создание сильных брендов / Д. Аакер. М. : Издательский Дом Гребенникова, 2003. - 440 с.

2. Андреева Г. М. Психология социального познания / Г. М. Андреева. - М. : Аспект Пресс, 2005. - 303 c.

3. Барабанщикова В. А. Основные направления и тенденции развития психологии восприятия / В. А. Барабанщикова // Психология восприятия: Материалы советско-норвежского симпозиума. - М. : Наука, 1989. - С. 5-14.

4. Бровкина Ю. Ю. Социально-психологические основы бренд-коммуникации : монографія / Ю. Ю. Бровкина. - М. : Изд- во Моск. гуманит. унта, 2009. $-331 \mathrm{c}$. consequences of environmental manmade disaster: monograph]. Kyiv: Slovo (Word) [in Ukrainian].

10. Felser, G. (2009). Psikhologiya potrebiteley i reklama [Consumers' psychology and advertising]. Kharkiv: "Humanitarian Centre" publishing house [in Russian].

11. Folomeieva, T. V., Vinokurov, F. N. (2012). Loyalnost potrebiteley kak sotsialnaya ustanovka [Customer loyalty as a social attitude]. Psikhologicheskie issledovaniya - Psychological studies, 5, 23. Retrieved from: http://psystudy.ru/index.php/num/2012v5n23/683-

folomeeva23.html

12. Kharash, A. U. (1981). Vospriyatie cheloveka kak vozdeystviie na ego povedeniie [Perception of a person as an influence on his/her behaviour]. Psikhologiya mezhlichnostnogo poznaniya - The psychology of interpersonal perception (pp. 25-42). Moscow: Pedagogics [in Russian]

13. Sharkov, F. I. (2006). Magiya brenda: Brending kak marketingovaya kommunikatsiya [Brand magic: Branding as marketing communication]. Moscow: AlfaPress [in Russian].

14. Shvalb, Yu. M., Vernik, O. L., Harnets, O. M., Liovochkina, A. M. (2008). Ekoloho-psykholohichni chynnyky suchasnoho sposobu zhyttia [Environmental and psychological factors of modern lifestyle: coll. Monograph]. Yu. M. Shvalb (Ed.). Kyiv: Pedahohichna dumka [in Ukrainian].

15. Brand communication. The Cambridge Business English Dictionary Cambridge University Press. Retrieved from: http://dictionary.cambridge.org/dictionary/english/brandcommunication [in English].

16. Gabay, J. (2015). Brand Psychology: Consumer Perceptions, Corporate Reputations. UK: Kogan Page [in English].

17. Oliver, R. L. (2010). Satisfaction: A Behavioral Perspective on the Consumer. $2^{\text {nd }}$ ed. New York: Routledge [in English].

18. Reichheld, F. F. (2003). The one number you need to grow. Harvard Business Review, 12, 46-54 (Vol. 81) [in English].

5. Голечьян Н. Эко-маркетинг: в чем выгода экологически благополучного имиджа компании / Н. Голечьян // Корпоративная имиджелогия. - 2008. - №2 (3). - С. 50-55.

6. Льовочкіна А. М. Принципи позитивності i конструктивності та екологічності як базові принципи екологічної психології / А. М. Льовочкіна // Актуальні проблеми психології: зб. наук.пр. Інституту психології імені Г. С. Костюка АПН України ; за ред. С. Д. Максименка. - К., 2010.- Т.7, Вип. 24, - С. 160-166

7. Мозер К. Психология маркетинга и рекламы / К. Мозер. - Х. : Изд-во «Гуманитарный центр», 2004. $-380 \mathrm{c}$. 
8. Паламарчук О. М. Екологічно орієнтована підприємницька діяльність у сучасному світі: психологічні аспекти: монографія / О.М.Паламарчук. 9. Скребець В. О. Екологічна психологія у віддалених наслідках екотехногенної катастрофи : монографія / В. О. Скребець - К. : Слово, 2004. - 440 с.

10. Фельсер Г. Психология потребителей и реклама / Г. Фельсер. - Х. : Изд-во «Гуманитарный центр», 2009. $-704 \mathrm{c}$

11. Фоломеева Т. В. Лояльность потребителей как социальная установка / Т. В. Фоломеева, Ф. Н. Винокуров // Психологические исследования. 2012. - Т. 5, № 23. - С. 5. [Електронний ресурс]. Режим доступу: http://psystudy.ru/index.php/ num/2012v5n23/683-folomeeva23.html

12. Хараш А. У. Восприятие человека как воздействие на его поведение // Психология межличностного познания / А. У. Хараш. - М. : Педагогика, 1981. C. $25-42$. Житомир : Вид-во ЖДУ ім. І. Франка, 2014. - 400 с.

13. Шарков Ф. И. Магия бренда: Брендинг как маркетинговая коммуникация / Ф. И. Шарков. - М. : Альфа-Пресс, 2006. - 266 с.

14. Швалб Ю. М. Еколого-психологічні чинники сучасного способу життя :кол.монографія ; за наук ред. Ю. М. Швалба / Ю. М. Швалб, О. Л. Вернік, О. М. Гарнець, А. М. Льовочкіна та ін. - К.: Пед. думка, 2008. - 276 с.

15. Brand communication / The Cambridge Business English Dictionary Cambridge University Press. [Електронний ресурс] / Режим доступу: http://dictionary. cambridge.org/dictionary/english/brand-communication

16. Gabay J. Brand Psychology: Consumer Perceptions, Corporate Reputations /Jonathan Gabay. UK :Kogan Page, 2015. - 440 p.

17. Oliver R. L. Satisfaction: A Behavioral Perspective on the Consumer / R. L. Oliver. - [2 ed.]- New York :Routledge, 2010.- $544 \mathrm{p}$.

18. Reichheld F. F. The one number you need to grow /F. F. Reichheld // Harvard Business Review.2003, - Vol. 81 - №. 12.- P. 46-54.

Лілія Петрівна Гомольська, здобувач кафедри соиіальної психології, Київький національний університет імені Тараса Шевченка, викладач суспільних наук, Київський інститут музики ім. Глісра, вул. Л.Толстого-31, м. Київ, Україна, 01032

\section{ТИПИ СПОЖИВАЧІВ ВІДПОВІДНО ДО СПРИЙМАННЯ} НИМИ ЕКОЛОГІЧНОСТІ БРЕНДУ В БРЕНД-КОМУНІКАЦІЯХ

У статті наведено результати дослідження особливостей сприймання українськими споживачами екологічності бренду в бренд-комунікаціях. Бренд-комунікація являє собою комплекс певних дій у процесі соціальної взаємодії (міжособистісної, міжгрупової, масової), які впливають на думку, мотиви, установки, поведінку споживачів щодо певних компаній, їх продуктів і (чи) послуг. Результатом бренд-комунікації є образ бренду як соціального об'єкту. Про ефективність бренд-комунікацій йдеться у випадку, коли сформований образ бренду формує лояльність споживачів як атитюд, що динамічно розвивається і мотивує індивідів до придбання та споживання відповідного продукту (послуги). За результатами емпіричного дослідження констатовано, що екологічність бренду є вагомим соціально-психологічним механізмом ефективності бренд-комунікацій. За результатами кластерного аналізу виокремлено 4 типи споживачів за сприйманням екологічності бренду в бренд- комунікаціях: «орієнтовані на особистісну значущість екологічності бренду», «орієнтовані на образ бренду, що створює виробник», «орієнтовані на конвенційний рівень бренд-комунікацій», «не орієнтовані на екологічність бренду». Виявлено статистично значущі відмінності у розподілі типів споживачів залежно від ряду соціально-демографічних та організаційно-професійних чинників. Так, зокрема, жінки більше, ніж чоловіки орієнтовані на особистісну значущість екологічності бренду, натомість серед чоловіків дещо більша представленість таких, що взагалі не орієнтовані на екологічність бренду. Серед молодших за віком споживачів більше тих, хто орієнтований на конвенційний рівень бренд-комунікації або взагалі не орієнтований на екологічність бренду в якості регулятора споживацької поведінки ( $<<0,01)$. За результатами дисперсійного аналізу визначено особливості лояльності споживачів залежно від сприйняття ними екологічності бренду як одного із соціально-психологічних механізмів ефективної бренд-комунікації для товарів продовольчої групи. Перспективи подальших досліджень полягають у визначенні сукупності соціально-психологічних механізмів і чинників ефективних бренд- комунікацій, теоретичному обгрунтуванню, розробленні та апробації соціально-психологічних програм підготовки майбутніх менеджерів, маркетологів, працівників рекламної сфери до ефективних бренд-комунікацій тощо.

Ключові слова: бренд, образ бренду, екологічність бренду, атитюд, бренд-комунікація, психологія споживача, лояльність.

Submitted on June, 6, 2017 